\title{
Digital Naïves Go Online
}

\author{
Rozália Klára BAKÓ \\ Sapientia Hungarian University of Transylvania \\ Cluj-Napoca, Romania \\ e-mail: bakorozalia@uni.sapientia.ro
}

\begin{abstract}
We live in a networked world with a fast pace of digitalization, and yet about half of the humanity is still offline (United Nations, 2018). Information and communication technologies are playing a key role in our public and private lives, both during work- and playtime. No wonder that social inequalities are increasingly reflected as digital inequalities in terms of infrastructural access, skills, and cultural practices online: those left behind can hardly keep up. The present research note brings together theoretical and practical resources related to digital inclusion issues globally, with local examples from Romania, where digital naïves - the poor, the rural, the elderly, the disabled, and the less educated - are more at risk. ${ }^{1}$
\end{abstract}

Keywords: digital naïves, digital inclusion, global perspective, local example, Romania

\section{From "Little Boxes" to "Networked Individualism"}

The Internet is nowadays embedded in daily community life, rather than a separate socio-technical system (Wellman et al., 2003). Virtual groups can be perceived as imagined communities of anonymous people with similar interests or values (Anderson, 2006). Concerns over online communication taking over face-to-face interactions, conceptualized by the Canadian sociologist and his NetLab, are louder than ever:

- Do we communicate more given the extra opportunity of online channels and tools?

- Do we favour these online, affordable channels over offline meetings?

- Do we have less offline time due to the growing amount of time spent online?

- Do we spend less time in offline communities due to the growing number of online groups?

- What kind of sense of belonging do we, networked people have?

1 Funded by Sapientia Foundation - Institute for Research Programmes, Romania. 
There is no simple answer to these questions formulated before the rise of social media platforms such as Facebook, YouTube, Twitter, and Instagram dominating online communication today, and there are multiple answers when it comes to children and teens (Bock-Macgilchrist, 2019; boyd, 2014). Living in a networked society brings about both opportunities and challenges (Benkler, 2006; Cardoso, 2006; Castells, 1999; Jenkins, 2006; Rainie-Wellman, 2014; Shirky, 2008; Van Dijk, 2006; Westera, 2013). Digital spaces enable and enhance what Wellman called "networked individualism" (2001) - an age of the individual with his/her sparsely knit ties, partially replacing small group units ("little boxes") as a frame of reference. The shift from the tightly knit groups to loose and geographically dispersed networks has happened gradually, with the Internet playing an instrumental role (Wellman et al., 2003; Wellman, 2018). Multimodal experience facilitated by information and communication technologies (ICTs) enables multiple identity layers, many of them anonymous (Bauerlein, 2011). Epitomized by the young woman hidden behind her laptop screen in a coffee shop, Bauerlein's Internet user - and possibly abuser - can go wherever she wants online, into spaces with no gatekeepers. "With the screen disengaging her from the surroundings, others nearby have no gatekeeping power" (2011: 132). In a way, we are all digital naïves: we may encounter challenges and traps in virtual worlds of deepfake videos and misleading information.

\section{Who Is Left Behind? The Need for Digital Inclusion Policies}

Can we connect easily and affordably to the Internet? Not all of us and not affordably. Do we understand what we find online? Not all of us and not all of it. There is a strong need for local content in terms of language and relevance since only a quarter of Internet users worldwide are English speakers, whereas half of the web content is in English (United Nations, 2018). Meanwhile, there is still a significant gender-based digital divide: "in 2017, about 51 per cent of men globally were online compared to about 45 per cent of women" (United Nations, 2018: 37). There are multiple digital divides globally, as shown in the table below.

Table 1. Multiple socio-economic and geo-cultural digital divides

\begin{tabular}{ll}
\hline Divide & Description \\
\hline Access & $\begin{array}{l}\text { Key infrastructural barrier as more people globally remain offline rather than stay } \\
\text { online }\end{array}$ \\
\hline Affordability & An important difference in adoption within countries and between them \\
\hline Age & Older people are using ICTs to a lesser extent than younger populations. \\
\hline Bandwidth & $\begin{array}{l}\text { Capacity to transmit and receive information varies between countries and } \\
\text { within them. }\end{array}$ \\
\hline
\end{tabular}




\begin{tabular}{ll}
\hline Divide & Description \\
\hline Content & Relevant content in local languages may stimulate adoption. \\
\hline Disability & If websites are not compliant with web accessibility guidelines \\
\hline Education & Education and literacy rates are fundamental challenges to bridge. \\
\hline Gender & A small, persistent difference in online usage between men and women \\
\hline Migration & $\begin{array}{l}\text { Digital literacy, content, and language divides encountered by migrants in their } \\
\text { new countries }\end{array}$ \\
\hline Location & $\begin{array}{l}\text { Rural and remote areas are often at a disadvantage in terms of speed and quality } \\
\text { of services }\end{array}$ \\
\hline Mobile & $\begin{array}{l}\text { Opportunities to bridge the access gap. New divides - technology, speed, and } \\
\text { usage }\end{array}$ \\
\hline Speed & $\begin{array}{l}\text { The gap between basic and broadband access makes it difficult to be part of the } \\
\text { digital culture. }\end{array}$ \\
\hline Useful usage & What people do with their access to take full advantage of the digital culture \\
\hline
\end{tabular}

Source: adapted from the United Nations report (2018: 34)

These gaps suggest some ways of bridging them by developing little daily practices or digital inclusion policies: supporting access, developing skills, helping the elderly, the less educated, and those more at risk to benefit from the digital culture.

\section{Digital Inclusion: Good Practices}

A simple and comprehensive definition states: "digital inclusion is whether a person can access, afford and have the digital ability to connect and use online technologies effectively" (Thomas et al., 2019: 8).

The World Wide Web Consortium's (W3C) accessibility standards ${ }^{2}$ show the long-lasting effort to bring the Internet closer to its users. Recommendations related to improving content and developing multimodal channels for online resources are aimed at easing the access of all categories of users to Internet, living temporarily or long-lasting with disabilities. Meanwhile, the Right to Repair movement brings infrastructural access closer to its users by supporting independent repair shops around the world and teaching users to fix their own devices instead of throwing them away - actions deeply rooted in environmental sustainability principles. ${ }^{3}$

Based on a thorough literature review, Tókés and Velicu (2015: 71) define the set of skills necessary for achieving digital competence: technical skills, or the ability to use ICTs in general; cognitive skills, or the ability to decode and properly interpret online messages; social skills, which are instrumental to interact in online spaces; last but not least, attitudes and personal perspectives enabling participation in

2 https://www.w3.org/WAI/standards-guidelines/wcag/

3 A good example is The Restart Project, at https://therestartproject.org/. 
digital life. Schools and civil society organizations may have a key role in fostering digital inclusion by working closely with those left behind, research has shown (Bakó, 2016; Bauerlein, 2011; Bock, Macgilchrist, 2019; Castells, 2004; Helsper, 2008; Meneses, Mominó, 2010; Van Deursen-Helsper, 2015).

Similarly, Van Deursen and Van Dijk (2010: 3) describe the Internet skills that should be developed for achieving a well-rounded digital literacy: operational Internet skills derived from basic skills in using Internet technology; formal Internet skills related to navigation and orientation online; information-seeking skills; strategic Internet skills aimed at using the Internet for improving one's position in society.

\section{Digital Divide in Romania}

There is a steady growth of Internet penetration rate in Romania, including mobile broadband penetration, as shown in Table 2.

Table 2. Evolution of the Internet penetration (IP) in Romania (2016-2018)

\begin{tabular}{lccc}
\hline \multicolumn{1}{c}{ Indicator } & $\mathbf{3 1 . 1 2 . 2 0 1 6}$ & $\mathbf{3 1 . 1 2 . 2 0 1 7}$ & $\mathbf{3 1 . 1 2 . 2 0 1 8}$ \\
\hline Landline IP for 100 households (\%) & 53.7 & 57.7 & 61.6 \\
\cline { 2 - 4 } - for urban areas & 67.5 & 70.9 & 73.7 \\
\cline { 2 - 5 } - for rural areas & 35.8 & 40.7 & 46.0 \\
\hline Mobile IP for 100 inhabitants (\%) & 96.4 & 98.9 & 102.0 \\
\hline Mobile IP for 100 inhabitants: 3G, 4G (\%) & 82.0 & 84.5 & 87.9 \\
\hline & & & Source: ANCOM (2019)
\end{tabular}

Despite the steady growth of broadband mobile Internet access across the country, Romania is still lagging behind when it comes to digital skills and attitudes/practices related to Internet use, as presented in the section below.

\section{Digital Economy and Society Index: Digitalization in Europe and Romania}

The Digital Economy and Society Index (DESI) measures the level of digitalization in the European Union (EU) countries, using five criteria and several indicators (European Commission, 2019):

- Connectivity: access to broadband Internet;

- Human capital: basic and advanced digital skills among the population;

- Use of Internet services: online content and transactions;

- Integration of digital technologies: e-business, e-commerce;

- Digital e-services: e-government and e-health. 
According to the latest report, Romania ranks 27 out of the 28 EU countries, with Finland on the top of the list, as shown in tables 3-7.

Table 3. Connectivity in Romania, Finland, and the EU (ranks in parenthesis)

\begin{tabular}{lccc}
\hline \multicolumn{1}{c}{ Indicators } & Romania & Finland & EU average \\
\hline $\begin{array}{l}\text { Fixed broadband coverage } \\
\% \text { households }\end{array}$ & $87 \%(26)$ & $94 \%(20)$ & $97 \%$ \\
\hline $\begin{array}{l}\text { Fixed broadband take-up } \\
\% \text { households }\end{array}$ & $66 \%(22)$ & $58 \%(27)$ & $77 \%$ \\
\hline $\begin{array}{l}\text { 4G coverage } \\
\% \text { households }\end{array}$ & $77 \%(28)$ & $99 \%(4)$ & $94 \%$ \\
\hline $\begin{array}{l}\text { Mobile broadband take-up } \\
\text { Subscriptions per 100 people }\end{array}$ & $85 \%(20)$ & $156 \%(2)$ & $96 \%$ \\
\hline $\begin{array}{l}\text { Fast broadband coverage } \\
\% \text { households }\end{array}$ & $76 \%(21)$ & $75 \%(24)$ & $83 \%$ \\
\hline $\begin{array}{l}\text { Fast broadband take-up } \\
\% \text { households }\end{array}$ & $55 \%(9)$ & $29 \%(22)$ & $60 \%$ \\
\hline $\begin{array}{l}\text { Super-fast broadband coverage } \\
\% \text { households }\end{array}$ & $75 \%(14)$ & $58 \%(19)$ & $20 \%$ \\
\hline $\begin{array}{l}\text { Super-fast broadband take-up } \\
\% \text { households }\end{array}$ & $45 \%(3)$ & $21 \%(14)$ & 87 \\
\hline $\begin{array}{l}\text { Broadband price } \\
\text { Score (0 to 100) }\end{array}$ & $86(16)$ & $94(1)$ & \\
\hline
\end{tabular}

While Romania ranks better than Finland for superfast broadband take-up ( $3^{\text {rd }}$ versus $14^{\text {th }}$ of the 28 countries), it is for the benefit of the young, urban, educated, and connected population.

Table 4. Human capital in Romania, Finland, and the EU (ranks in parenthesis)

\begin{tabular}{lccc}
\hline \multicolumn{1}{c}{ Indicators } & Romania & Finland & EU average \\
\hline $\begin{array}{l}\text { At least basic digital skills } \\
\% \text { individuals }\end{array}$ & $29 \%(28)$ & $76 \%(4)$ & $57 \%$ \\
\hline $\begin{array}{l}\text { Above basic digital skills } \\
\% \text { individuals }\end{array}$ & $10 \%(28)$ & $45 \%(6)$ & $31 \%$ \\
\hline $\begin{array}{l}\text { ICT specialists } \\
\% \text { total employment }\end{array}$ & $2.1 \%(27)$ & $6.8 \%(1)$ & $3.8 \%$ \\
\hline $\begin{array}{l}\text { Female ICT specialists } \\
\% \text { female employment }\end{array}$ & $1.3 \%(16)$ & $3.1 \%(1)$ & $1.4 \%$ \\
\hline $\begin{array}{l}\text { ICT graduates } \\
\% \text { graduates }\end{array}$ & $4.9 \%(6)$ & $7.1(1)$ & $3.5 \%$ \\
\hline
\end{tabular}

Source: compilation based on EC 2019b, EC 2019C

When it comes to basic and above basic digital skills, Romania ranks the worst among EU countries. This result will be further reflected in the low level of ICT use among the population and businesses, as shown further in tables 5 and 6 . 
The only competitive result for Romania is related to ICT graduates, ranking $6^{\text {th }}$ among EU countries.

Table 5. Use of Internet services in Romania, Finland, and the EU (ranks in parenthesis)

\begin{tabular}{lccc}
\hline \multicolumn{1}{c}{ Indicators } & Romania & Finland & EU average \\
\hline $\begin{array}{l}\text { Never used the Internet } \\
\% \text { individuals }\end{array}$ & $21 \%(24)$ & $4 \%(6)$ & $11 \%$ \\
\hline $\begin{array}{l}\text { Internet users } \\
\% \text { individuals }\end{array}$ & $68 \%(27)$ & $93 \%(4)$ & $83 \%$ \\
\hline $\begin{array}{l}\text { News } \\
\% \text { Internet users }\end{array}$ & $69 \%(24)$ & $90 \%(4)$ & $72 \%$ \\
\hline $\begin{array}{l}\text { Music, video, and games } \\
\% \text { Internet users }\end{array}$ & $63 \%(28)$ & $94 \%(1)$ & $81 \%$ \\
\hline $\begin{array}{l}\text { Social networks } \\
\% \text { Internet users }\end{array}$ & $86 \%(1)$ & $71 \%(17)$ & $65 \%$ \\
\hline $\begin{array}{l}\text { Professional social networks } \\
\% \text { Internet users }\end{array}$ & $6 \%(25)$ & $20 \%(6)$ & $15 \%$ \\
\hline $\begin{array}{l}\text { Doing an online course } \\
\% \text { Internet users }\end{array}$ & $5 \%(23)$ & $17 \%(2)$ & $64 \%$ \\
\hline $\begin{array}{l}\text { Banking } \\
\% \text { Internet users }\end{array}$ & $10 \%(28)$ & $94 \%(1)$ & $69 \%$ \\
\hline $\begin{array}{l}\text { Shopping } \\
\% \text { Internet users }\end{array}$ & $26 \%(28)$ & $74 \%(8)$ & $90196, E C 2019 c$
\end{tabular}

More than $20 \%$ of Romanians have never used the Internet, below the EU average, while those who use it excel mainly on social networks ( $1^{\text {st }}$ among the EU countries, the only outstanding Romanian "performance"). Small- and medium-sized enterprises perform no better than individuals in terms of digital services adoption, as shown in Table 6 .

Table 6. Integration of digital technologies in Romania, Finland, and the EU (with ranks)

\begin{tabular}{lccc}
\hline \multicolumn{1}{c}{ Indicators } & Romania & Finland & EU average \\
\hline $\begin{array}{l}\text { Electronic information services } \\
\% \text { enterprises }\end{array}$ & $17 \%(27)$ & $39 \%(9)$ & $34 \%$ \\
\hline $\begin{array}{l}\text { Social media } \\
\% \text { enterprises }\end{array}$ & $9 \%(27)$ & $29 \%(6)$ & $21 \%$ \\
\hline $\begin{array}{l}\text { Big data } \\
\% \text { enterprises }\end{array}$ & $11 \%(14)$ & $19 \%(5)$ & $12 \%$ \\
\hline $\begin{array}{l}\text { Cloud } \\
\% \text { enterprises }\end{array}$ & $7 \%(25)$ & $50 \%(1)$ & $18 \%$ \\
\hline $\begin{array}{l}\text { SMEs selling online } \\
\% \text { SMEs }\end{array}$ & $8 \%(27)$ & $20 \%(8)$ & $8 \%$ \\
\hline $\begin{array}{l}\text { SMEs selling online cross-border } \\
\% \text { SMEs }\end{array}$ & $2 \%(28)$ & $6 \%(23)$ & $17 \%$ \\
\hline
\end{tabular}


Romania has performed best for big data service integration, above the EU average, and worst for online selling cross-border among small and mediumsized enterprises - ranking 28 of 28. The situation is no better for digital public services, as shown in Table 7.

Table 7. Digital public services in Romania, Finland, and the EU (ranks in parenthesis)

\begin{tabular}{lccc}
\hline \multicolumn{1}{c}{ Indicators } & Romania & Finland & EU average \\
\hline $\begin{array}{l}\text { E-government users } \\
\text { \% Internet users needing to } \\
\text { submit }\end{array}$ & $82 \%(7)$ & $92 \%(3)$ & $64 \%$ \\
\hline $\begin{array}{l}\text { Pre-filled forms } \\
\text { Score (0 to 100) }\end{array}$ & $10 \%(28)$ & $82 \%(5)$ & $58 \%$ \\
\hline $\begin{array}{l}\text { Online service completion } \\
\text { Score (0 to 100) }\end{array}$ & $67 \%(27)$ & $96 \%(5)$ & $87 \%$ \\
\hline $\begin{array}{l}\text { E-public services for businesses } \\
\text { Score (0 to 100) }\end{array}$ & $54 \%(28)$ & $96 \%(6)$ & $85 \%$ \\
\hline $\begin{array}{l}\text { Open data } \\
\% \text { of maximum score }\end{array}$ & $62 \%(18)$ & $62 \%(19)$ & $18 \%$ \\
\hline $\begin{array}{l}\text { E-health services } \\
\% \text { individuals }\end{array}$ & $11 \%(21)$ & $49 \%(1)$ & $43 \%$ \\
\hline $\begin{array}{l}\text { Medical data exchange } \\
\% \text { general practitioners }\end{array}$ & $19 \%(24)$ & $65 \%(7)$ & $50 \%$ \\
\hline $\begin{array}{l}\text { E-prescriptions } \\
\% \text { general practitioners }\end{array}$ & $39 \%(18)$ & $99 \%(2)$ & \\
\hline
\end{tabular}

Source: compilation based on EC 2019b, EC 2019C

Availability and take-up of e-government services in Romania lag behind other European countries despite a dynamic and competitive IT sector and substantial investment via the World Bank and the EU (Bakó, 2016).

\section{Conclusions}

The case of Romania shows that more access does not mean more understanding of what Internet is and how it should be used efficiently. On the contrary: it creates more risks and paranoia (Herian, 2019) given the digital naïves unaware of the security risks and unable to protect themselves from scams, personal data phishing, and cyberbullying. The faster infrastructural access grows without efforts invested in developing digital literacy, the more challenges individuals and organizations face.

Schools and civil society organizations can play an important role in bridging multiple digital divides but cannot replace digital inclusion policies set by governments and other big players such as the tech industry giants, always hungry for new users yet slow to stop abusers. 


\section{References}

Anderson, B. (2006). Imagined Communities. London-New York: Verso.

ANCOM (Autoritatea Națională pentru Administrare şi Reglementare în Comunicații). (2019). Piața serviciilor de comunicații electronice din România. Raport de date statistice - semestrul II 2018. <www.ancom.org.ro> (accessed on: 3 November 2019).

Bakó, R. K. (2016). Romania: Participatory Culture and the Internet. Global Information Society Watch 2016. Economic, Social and Cultural Rights and the Internet, 189-193.

Bauerlein, M. (ed.), 2011. The Digital Divide. London-New York: Penguin Group. Kindle Edition.

Benkler, Y. (2006). The Wealth of Networks. How Social Production Transforms Markets and Freedom. New Haven-London: Yale University Press.

Bock, A.-Macgilchrist, F. (2019). Mobile Media Practices of Young People in «Safely Digital», «Enthusiastically Digital», and «Postdigital» Schools. MedienPädagogik 35: 136-156 <https://doi.org/10.21240/ mpaed/35/2019.10.23.X.> (accessed on: 3 November 2019).

boyd, d. (2014). It's Complicated: The Social Lives of Networked Teens. New Haven-London: Yale University Press.

Cardoso, G. (2006). The Media in the Network Society: Browsing, News, Filters and Citizenship. Lisbon: Centre for Research and Studies in Sociology.

Castells, M. (1999). Toward a Sociology of the Network Society. Contemporary Sociology 29(5): 693-699.

(ed.). (2004). The Network Society: A Cross-cultural Perspective. Cheltenham, UK-Northampton, MA, US: Edward Elgar.

European Commission. (2019a). Digital Economy and Society Index, $2019<\mathrm{https}$ // ec.europa.eu/digital-single-market/en/desi> (accessed on: 3 November 2019). (2019b). Digital Economy and Society Index, 2019. Finland <https://ec.europa. eu/digital-single-market/en/scoreboard/finland> (accessed on: 3 November 2019).

(2019c). Digital Economy and Society Index, 2019. Romania <https://ec.europa. eu/digital-single-market/en/scoreboard/romania> (accessed on: 3 November 2019).

Helsper, E. (2008). Digital Inclusion: An Analysis of Social Disadvantage and the Information Society. London: London School of Economics.

Herian, R. (2019). Tokens of Technical Progress: Blockchains, Data Dysphoria \& Fantasies of Control. The World Financial Review September-October: 66-69. Jenkins, H. (2006). Confronting the Challenges of Participatory Culture: Media Education for the $21^{\text {st }}$ Century. Chicago: MacArthur Foundation. 
Meneses, J.-Mominó, J. M. (2010). Putting Digital Literacy in Practice: How Schools Contribute to Digital Inclusion in the Network Society. The Information Society 26: 197-208.

Rainie, L.-Wellman, B. (2014). Networked: The New Social Operating System. Cambridge, MA: MIT Press.

Shirky, C. (2008). Here Comes Everybody: The Power of Organizing without Organizations. London-New York-Toronto: Penguin.

Thomas, J.-Barraket, J.-Wilson, C. K.-Rennie, E.-Ewing, S.-MacDonald, T. (2019). Measuring Australia's Digital Divide: The Australian Digital Inclusion Index 2019. Melbourne: RMIT University and Swinburne University of Technology, for Telstra.

Tókés, G.-Velicu, A. (2015). “I Learned All by Myself”: Romanian Young People’s Self-Perception of Their Digital Competence. Acta Universitatis Sapientiae, Communicatio 2: 67-91.

United Nations, 2018. United Nations e-Government Survey 2018. Gearing e-Government to Support Transformation towards Sustainable and Resilient Societies. New York: United Nations Department of Economic and Social Affairs.

Van Deursen, A.-Helsper, E. (2015). The Third Level Digital Divide: Who Benefits Most from Being Online? Communication and Information Technologies Annual: Digital Distinctions and Inequalities. Studies in Media and Communications 10: 29-53.

Van Deursen, A.-Van Dijk, J. (2010). Internet Skills and the Digital Divide. New Media and Society XX(X): 1-19.

Van Dijk, J. (2006). The Network Society. London-Thousand Oaks-New Delhi: Sage Publications.

Wellman, B. (2001). Little Boxes, Glocalization, and Networked Individualism. Kyoto Workshop on Digital Cities 2001. Digital Cities II: Computational and Sociological Approaches, 10-25.

(ed.). 2018. Networks in the Global Village. Life in Contemporary Communities. New York-London: Routledge.

Wellman, B.-Quan-Haase, A.-Boase, J.-Chen, W.-Hampton, K.-Díaz, I.Miyata, K. (2003). The Social Affordances of the Internet for Networked Individualism. Journal of Computer-Mediated Communication 8(3) <https:// doi.org/10.1111/j.1083-6101.2003.tb00216.x>.

Westera, W. (2013). The Digital Turn: How the Internet Transforms Our Existence. Bloomington: Author House (accessed on: 3 November 2019). 